\title{
Hip fracture epidemiological trends, outcomes, and risk factors, 1970-2009
}

\author{
This article was published in the following Dove Press journal: \\ International Journal of General Medicine \\ 15 December 2009 \\ Number of times this article has been viewed
}

\author{
Ray Marks \\ City University of New York \\ and Columbia University, \\ New York, NY, USA
}

Correspondence: Ray Marks

Columbia University, Teachers College,

Department of Health and Behavior

Studies, Box II4, 525W 120th Street,

New York, NY 10027, USA

Tel +l 2/2 6783445

Fax +I 2126788259

Email rm226@columbia.edu
Abstract: Hip fractures - which commonly lead to premature death, high rates of morbidity, or reduced life quality - have been the target of a voluminous amount of research for many years. But has the lifetime risk of incurring a hip fracture decreased sufficiently over the last decade or are high numbers of incident cases continuing to prevail, despite a large body of knowledge and a variety of contemporary preventive and refined surgical approaches? This review examines the extensive hip fracture literature published in the English language between 1980 and 2009 concerning hip fracture prevalence trends, and injury mechanisms. It also highlights the contemporary data concerning the personal and economic impact of the injury, plus potentially remediable risk factors underpinning the injury and ensuing disability. The goal was to examine if there is a continuing need to elucidate upon intervention points that might minimize the risk of incurring a hip fracture and its attendant consequences. Based on this information, it appears hip fractures remain a serious global health issue, despite some declines in the incidence rate of hip fractures among some women. Research also shows widespread regional, ethnic and diagnostic variations in hip fracture incidence trends. Key determinants of hip fractures include age, osteoporosis, and falls, but some determinants such as socioeconomic status, have not been well explored. It is concluded that while more research is needed, well-designed primary, secondary, and tertiary preventive efforts applied in both affluent as well as developing countries are desirable to reduce the present and future burden associated with hip fracture injuries. In this context, and in recognition of the considerable variation in manifestation and distribution, as well as risk factors underpinning hip fractures, well-crafted comprehensive, rather than single solutions, are strongly indicated in early rather than late adulthood.

Keywords: epidemiology, disability, hip fractures, injury, prevention, risk factors

\section{Background to the problem}

For many years hip fracture injuries have been identified as one of the most serious health care problems affecting older people. Much attention has consequently been placed on comprehensive efforts to reduce the incidence and severity of this condition. Indeed, some recent evidence suggests these efforts have met with some degree of success. ${ }^{1,2}$ However, the literature is unequivocal in this regard. Moreover, several current reports confirm hip fractures remain a leading cause of excessive morbidity, and premature mortality among older people. ${ }^{3,4}$ Thus, despite some positive downward trends in hip fracture incidence rates, ${ }^{5}$ these may not be occurring universally or rapidly enough to offset the immense human and social costs projected to persist over the next several decades. ${ }^{6}$ 
That is, given that hip fracture incidence rates rise exponentially with age, and that age specific hip fracture rates are rising for subsequent cohorts, ${ }^{7}$ as longevity increases across the globe, ${ }^{8}$ along with sedentary lifestyles that correlate with several key hip fracture determinants, it seems reasonable to speculate hip fractures will remain a serious world wide public health problem as proposed by Wehren and Magaziner in 2003. ${ }^{6}$ To this end, this paper explores if there is sufficient current support for this premise, and if so, whether concerted efforts towards prevention are desirable. By analogy it also explores whether long-term costs of this health problem of nearly US\$9 billion dollars in $1995^{6}$ are also likely to rise, first, because an increasing body of older people survive after hip fracture injuries as a result of better acute care. Second, because these survivors commonly encounter various degrees of progressive disability that require long-term care and extensive ongoing services. ${ }^{6}$ Third, as more adults reach the age of 85 years, these adults who are commonly in precarious health or recover more slowly when injured than younger adults, are 10-15 times more likely than those younger than 85 years to fracture a hip. ${ }^{9}$

It is the author's view that hip fractures will continue to be of substantive importance to public health planners, particularly if as predicted, a vast majority of these injuries in the 21 st century will occur in developing countries ${ }^{10}$ where the resources to deal with this problem are likely to be somewhat undeveloped, underfunded and technologically suboptimal. Another related issue is that a high percentage of hip fractures are linked with osteoporosis, which is an escalating global problem. Additionally, hip fractures, the most catastrophic complication of osteoporosis, continue to result in significant mortality and morbidity rates despite the increasing availability of effective preventative agents. ${ }^{11}$ Lastly, the costs of care for this debilitating injury are immense because they are not limited solely to the costs of functional disability and increased death rates, ${ }^{8}$ but commonly to several other factors including, a loss of the ability of the injured adult to function independently, the related costs of nursing care, rehabilitation care, and need for one or more surgeries. Thus, rather than becoming complacent given some progress in reducing anticipated rates of hip fracture in some regions, continued vigilance, plus the implementation of widespread cost-effective preventive strategies against hip fractures, as stressed by Wilson and Wallace ${ }^{8}$ and Haleem and colleagues ${ }^{3}$ remain strongly indicated.

However, to secure support for efforts to prevent hip fractures and their debilitating outcomes within an economic climate that often demands service cutbacks and fiscal restraint, and a science base that does not always stress the economic and social value of prevention, the rationale for this approach must be clearly depicted. That is, a clear case must first be made for why the issue merits specific attention, and thereafter, for what specific strategies might be set in place or emphasized to minimize the related human and economic impact.

To this end, the present review reports pertinent data from the available peer-reviewed literature detailing the distribution and possible casual factors related to hip fractures published in the peer-reviewed literature over the last 30 years. Also reported are some findings regarding second hip fractures, an often overlooked, albeit important, associated outcome of the initial injury. As well, information depicting the economic and human impact of this condition, a topic not often detailed in the related literature is presented. Finally, some recommendations for improving our understanding of this health condition including potential preventive directives against first and second hip fractures, and their debilitating consequences are provided.

\section{Methods}

The literature reviewed was primarily accessed from an array of research based articles written in English, and located in the Medline and PubMed databases and published between 1980-2009. Key terms used were: 'hip fracture', 'epidemiology', 'incidence', 'prevalence', 'risk factors'. All related articles that reported on hip fracture rehabilitation or surgery were excluded from the report. The pertinent data was carefully examined and then categorized into the key themes of interest: distribution and prevalence, outcomes and risk factors. In terms of the author's aims, as well as space limitations, only those risk factors deemed both consistently salient and amenable to prevention are highlighted. The magnitude and extent of the disability is included to draw attention to the need for reducing the incidence and severity of this debilitating condition. In keeping with the broad aims of the paper, the review approach adopted was largely a narrative one, and an attempt was made to simplify and tabulate themes of importance. Based on the high numbers of reports from well known research establishments and researchers, and the consistency of many reports from diverse laboratories and regions, regardless of study design, an assumption was made that the reports reviewed provided consistently valid conclusions.

\section{Descriptive epidemiology}

\section{Hip fracture trends 1970-2009}

While somewhat variable, data published since the early 1990s describing the occurrence of hip fractures across 
the globe has generally shown the age-adjusted incidence of this injury is increasing ${ }^{3,6}$ or is projected to increase. ${ }^{12}$ Accordingly, it was initially predicted that if there was a steady increase in the numbers of United States residents reaching the age of 85 years or older, ${ }^{13}$ the numbers of elderly at risk for a hip fracture would double by 2007 . That is, the total number of hip fracture cases in later life was not only expected to remain significant, but was projected to rise substantively. ${ }^{8}$ At the same time, this age-associated trend in longevity was not only influencing hip fracture risk in the United States, but was also evident in The People's Republic of China where hip fracture rates, once amongst the lowest in the world compared with more affluent countries, ${ }^{14}$ increased by $34 \%$ for women and 33\% for men between 1988 to $1992 .{ }^{15}$ Similarly, in Finland, the whole population incidence rate increased approximately three fold between 1970 and 1991 with respect to both genders, ${ }^{16}$ and between 1970 and 1997 , the age-specific incidence of hip fractures increased in all age groups. ${ }^{17}$

Likewise, linear increases of age-adjusted fracture incidences for men and women were reported in the Netherlands between 1972-1987 and the analysis also showed that this age-specific incidence increase was higher than that of earlier birth cohorts. ${ }^{18}$ Similar trends were noted in Japan where hip fracture incidence rates for both genders were shown to increase exponentially with age after the age of 70 years with an annual incidence among women aged 85 years and older of 2,000 cases. ${ }^{19}$ Rates in Sweden from 1966-1986 were also found to increase from 3.3 per 1,000 inhabitants to 5.1 for persons aged more than 50 years, and almost doubled in persons aged more than 80 years, with a proportional increase that was greatest for men and city dwellers. ${ }^{20}$

Indeed, despite some evidence of declining hip fracture incidence rates in North America ${ }^{21}$ and among some Swiss women, ${ }^{22}$ as people live longer, and the average age of the hip fracture patient continues to increase from $73-79$ years, ${ }^{3}$ it is possible the total number of hip fractures in the world, estimated at 1.7 million in $1990^{16}$ will still rise exponentially to 6.3 million by the year $2050 .{ }^{23}$ In support of this argument, it has been noted that even in those regions of the United States where downturns in hip fracture incidence rates have been recorded, ${ }^{21}$ there are still increasing numbers of adults living to higher ages. In addition, rates of downturn over a 10-year period from 1991-200022 may only reflect declines among standardized hip fracture incidence rates of institution-dwelling women, rather than a general reversal in secular trends. ${ }^{5}$ Further, the fact that more older United States adults had low femoral neck bone mass density in 2005-2006 than in 1988-1994, implies the number of United States adults at risk for future hip fractures will remain high. ${ }^{24}$ Other estimates are that there will be a sevenfold increase between the present time and 2050 in Belgium ${ }^{25}$ that will be greater in men than women if no comprehensive preventive policy is set up, and marked increases in Asia where the highest absolute increment in the elderly population will be observed. ${ }^{26}$

Moreover, high incidence rates continue to prevail in some northern Europe regions ${ }^{16}$ and these are expected to rise. ${ }^{6}$ In Germany, for example, a call for improving and developing prevention strategies against hip fractures attributable to osteoporosis currently prevails because 2050 projections of this condition are expected to increase costs exponentially between 2020 and 2050 due to changing demographics. ${ }^{27}$ In Australia, the number of hip fractures is similarly expected to double over 29 years and quadruple in 56 years. ${ }^{28}$ Furthermore, data published in 2008 covering the years 1994-2006 in Austria, showed that in contrast to findings in some countries, there has been no levelling-off or downward trend of hip fracture incidence in the Austrian elderly population. After adjusting for age and gender, the fracture increase, while small was significant and rose numerically from 11,694 in 1994 to 15,987 in $2006 .^{29}$

\section{Summary}

While many studies conducted in the 1990s predicted increasing hip fracture prevalence rates in the 21 st century, the current literature reveals some levelling off of these rates, especially among individuals at risk for osteoporosis. However, as the number of older adults living to higher ages increases globally, the total numbers of hip fracture cases and their related expenditures are likely to rise substantively. ${ }^{27}$ Moreover, even if some of the aforementioned data do not take into account more recent bone sparing pharmacologic interventions ${ }^{3}$ and other experimental therapies that may prevent hip bone loss, ${ }^{30}$ some published data reporting an age-specific flattening of the incidence of hip fractures, ${ }^{31,32}$ may be underestimates because they often exclude hip fracture injury cases or injuries that have occurred have not been accurately coded. ${ }^{3}$

Hip fracture incidence may also be hard to capture with precision because rates may vary depending on seasonality, ${ }^{33}$ geography, ${ }^{34-37}$ and factors other than aging. ${ }^{34}$ These include health status, ${ }^{38}$ ethnicity, ${ }^{38,39}$ gender, ${ }^{40-44}$ neuromuscular status, ${ }^{45}$ extent of urbanization, ${ }^{46}$ along with year of immigration to the United States, ${ }^{47}$ the availability, nature, and potency of current therapeutic and/or preventive measures. ${ }^{38,48}$ The method of deducing trends in hip fracture and their 
results can also vary substantively with the model used as demonstrated by Fisher and colleagues in the Australian context. ${ }^{48}$ In addition, along with the large variation in the age, gender, and geographic distribution of hip fractures within and across countries, ${ }^{44,49,50}$ especially challenging in efforts to effectively capture the true global burden of hip fractures is the fact there are three distinctive hip fracture sub-types, each with potentially different risk factor profiles ${ }^{51-53}$ and prevalence rates. ${ }^{54-60}$

Although it is not possible to prove or disprove, it seems that the strong correlation between aging and hip fractures favors the prediction that hip fracture incidence rates will rise by $1 \%-3 \%$ per year in most areas of the world for both men and women in the years to come. ${ }^{61,62}$ In addition to the aging factor, a widespread lack of awareness of the importance of osteoporosis persists and prevents the widespread use of drugs with anti-fracture efficacy. ${ }^{63}$ Moreover, because not all hip fractures are related to osteoporosis, ${ }^{62,64}$ but these risk factors may not be addressed or followed-up at all adequately, ${ }^{64}$ the health care system and societal costs of hip fractures are projected to increase if concerted preventive efforts with 'new, effective and widely applicable strategies' are not forthcoming. ${ }^{65-67}$ These projected costs include, but are not limited to, avoidable deaths, disability, and rising costs due to higher numbers of discharges of posthip fracture patients to continuing care institutions. ${ }^{68}$

In addition to the above mentioned factors, adults who sustain intertrochanteric fractures, whose numbers increase progressively with age, experience higher mortality, morbidity, and costs than those of cervical fractures. ${ }^{16}$ As well, despite declining hip fracture reoccurrence rates greater than anticipated in recent years, ${ }^{69}$ adults who have sustained a hip fracture are commonly susceptible to subsequent hip fractures. That is, a second hip fracture, which may be in the same location with a tendency to greater displacement or instability occurs about $6 \%$ of the time and within a fouryear period post-fracture. ${ }^{70}$ Further, if Dolk ${ }^{71}$ is correct, the frequency of sustaining two hip fractures over the course of an individual's lifetime could reach $20 \%$. Furthermore, because new hip fractures may occur on the same side as well on the opposite side to an initial fracture, it may be possible to sustain three hip fractures over time, and according to Shroder and colleagues ${ }^{72}$ the risk of incurring a third hip fracture per 1,000 men is 8.6 and 9.8 per 1000 women, per year.

Prevention here is key again because there is no well defined pattern to clearly predict who is at risk, because contributory risk factors other than osteoporosis, ${ }^{73}$ as well as untreated osteoporosis after the first fracture can be implicated in mediating two episodes of fragility fractures. ${ }^{74}$ Other data show the incidence rate for second hip fractures can be higher than that of first hip fractures, ${ }^{75}$ and as discussed by Berry and colleagues ${ }^{76}$ one year mortality rates can be approximately $10 \%$ higher following a second hip fracture than an initial fracture. ${ }^{76}$

However, pursuing the means to prevent first and second hip fractures is very challenging, because as outlined above, and reiterated by Thomas and colleagues, ${ }^{77}$ the risk of hip fracture, which rises 100-1000-fold over six decades of age is only explained in a minor way by declining bone mineral density. Several other risk factors for hip fractures that may serve as additional therapeutic targets may be helpful for reducing the rate and severity of the hip fracture injury and its costs (see Table 1) have been the focus of a large volume of research. The predominant determinants that have been studied are discussed below and were selected as representative of those deemed consistently important as well as amenable to intervention.

\section{Risk factors for hip fracture Biomechanical factors \\ Falls}

In the early $1990 \mathrm{~s}$, research by Hayes and colleagues ${ }^{65}$ demonstrated that over $90 \%$ of hip fractures are associated with falls. Since that time, an additional body of evidence has revealed a strong association between several diverse falls-related mediators and hip fracture injuries that may be useful intervention points in efforts to reduce hip fracture incidence rates. These include: balance impairments, ${ }^{45,78}$ neuromuscular and musculoskeletal impairments, ${ }^{79}$ fall type,${ }^{80}$ fall severity, and fall speed ${ }^{65}$ In addition, the presence of ineffective or suboptimal protective responses, along with age-associated strength decreases, ${ }^{81}$ cognitive impairment, ${ }^{82}$ and fear of falling, a serious disorder in older people, may increase the risk of falling and fracturing the hip. ${ }^{83}$ Declines in visual perception, proprioception and/or transient circulatory insufficiencies, ${ }^{68,84}$ as well as impaired sensory-motor integration functioning, ${ }^{85}$ and unexpected perturbations are additional determinants.

\section{Physical inactivity}

A sizeable body of research over the last 30 years has also shown physically inactive elderly adults are more than twice as likely as active adults to be at risk for hip fractures (see Table 2). ${ }^{35,86-89}$ Indeed, due to its highly negative impact on bone health, muscle physiology, muscle mass, overall health status, and on vitamin D exposure,,${ }^{90,91}$ physical inactivity is 
Table I Summary of studies depicting high monetary costs of treating hip fracture cases in different countries

\begin{tabular}{|c|c|c|}
\hline Author & Sample and site & Outcome \\
\hline Konnopka et a ${ }^{27}$ & $\begin{array}{l}\text { I08,34I osteoporosis attributable hip fractures } \\
\text { Germany, } 2002\end{array}$ & $\begin{array}{l}\text { Cost of care was } 2,998,000,000 \text { Euros and there } \\
\text { were } 3,485 \text { deaths }\end{array}$ \\
\hline Koeck et al ${ }^{62}$ & $\begin{array}{l}\text { I I,379 patients with osteoporotic hip fractures } \\
\text { Austrian hospitals, } 1995\end{array}$ & $\begin{array}{l}6.8 \% \text { died during hospitalization } 250,268 \text { bed days } \\
\text { were required overall } \\
\text { Total cost was US } \$ 103,509,800 \\
\text { Average cost per patient was US } \$ 9097\end{array}$ \\
\hline Azhar et a ${ }^{67}$ & $\begin{array}{l}\text { I } 43 \text { cases with hip fracture Major Irish } \\
\text { University Hospital, } 2005\end{array}$ & $\begin{array}{l}\text { Average costs per patient was } \$ 9326 \text { Euros } \\
\text { Average length of stay was II days }\end{array}$ \\
\hline Luppuner et al ${ }^{63}$ & $\begin{array}{l}62,535 \text { hospitalization for fracture Switzerland, } \\
2000\end{array}$ & $\begin{array}{l}\text { Hospitalization for hip fractures accounted for half } \\
\text { of the total } 357 \text { million CHF costs } \\
\text { The hospital costs were lower than in } 1992 \text { but did } \\
\text { not include costs of ambulatory care }\end{array}$ \\
\hline Tanriover et al ${ }^{196}$ & $\begin{array}{l}50 \text { cases of hip fracture, in Turkey, mean age } \\
74.2 \text { years were followed between } 2003 \\
\text { and } 2006\end{array}$ & $\begin{array}{l}\text { The mean hospital expenditure was } \$ 5,983 \\
\text { Factors affecting the total cost were age, functional } \\
\text { status, duration of hospital stay }\end{array}$ \\
\hline Bass et al ${ }^{197}$ & $\begin{array}{l}\text { Retrospective analysis of national veteran } \\
\text { hospital eligible Medicare patients with hip } \\
\text { fracture 1999-2002 in Medicare and Veterans } \\
\text { Health Administration Facilities }\end{array}$ & $\begin{array}{l}\text { Medicare reimbursed providers for nearly } \$ 3 \text { billion } \\
\text { in first year of injury. Mean annual payment per } \\
\text { patient was } \$ 69,389\end{array}$ \\
\hline Lawrence et al ${ }^{198}$ & $\begin{array}{l}\text { Costs of acute care for } 100 \text { patients with hip } \\
\text { fracture was conducted in the United Kingdom } \\
\text { in } 2003\end{array}$ & $\begin{array}{l}\text { The mean length of stay was } 23 \text { days at a cost of } \\
12,163 \text { pounds sterling per person of which ward } \\
\text { costs contributed } 84 \%\end{array}$ \\
\hline
\end{tabular}

currently proffered as the most salient explanatory factor for the increasingly high hip fracture rates reported by developing countries, as well as many first-world countries. ${ }^{85}$

\section{Muscle weakness}

Several researchers have concluded that muscle weakness, commonly associated with slower reflex responses ${ }^{83}$ can significantly increase the chances of falling due to unexpected perturbations, thus heightening the risk of fracturing a hip. ${ }^{65,92,93}$ Related research shows low levels of muscular strength can also heighten the risk of sustaining a hip fracture ${ }^{88}$ because of its long term negative impact on bone density ${ }^{94}$ and muscle shock absorbing capacity. ${ }^{95}$ Not surprisingly, an increased risk of falling and sustaining a hip fracture has been specifically noted in association with muscular impairments at the ankle, ${ }^{78}$ hip and knee,${ }^{59,85,96,97}$ low body strength in general, ${ }^{89,96}$ and lower limb dysfunction. ${ }^{98}$

\section{Body anthropometrics}

While body height, a nonmodifiable factor, may predispose towards a hip fracture, ${ }^{80,94,99-106}$ as outlined in Table 3 , there is a consistent association between the presence of a low body

Table 2 Research evidence showing a strong relationship between physical activity participation and hip fracture risk in prospective studies

\begin{tabular}{|c|c|c|}
\hline Authors & Study design & Finding \\
\hline Wickham et $\mathrm{al}^{87}$ & $\begin{array}{l}\text { I5 year follow-up study of } 1688 \text { community } \\
\text { dwelling subjects }\end{array}$ & $\begin{array}{l}\text { Physical activity participation protected against } \\
\text { hip fracture }\end{array}$ \\
\hline Hoidrup et al ${ }^{99}$ & $\begin{array}{l}\text { Prospective study of leisure-time physical } \\
\text { activity levels and changes in relation to } \\
\text { risk of hip fracture among I,2I I men and } \\
\text { women with first hip fractures }\end{array}$ & $\begin{array}{l}\text { Moderate levels of physical activity appear to } \\
\text { protect against later hip fracture } \\
\text { Declining physical activity over time is an } \\
\text { important risk factor for hip fracture }\end{array}$ \\
\hline Cawthon et al ${ }^{101}$ & $\begin{array}{l}\text { Prospective study of performance on } \\
5 \text { physical function exams among } 5902 \text { men } \\
65 \text { years of age or older }\end{array}$ & $\begin{array}{l}\text { Poor physical performance was associated with } \\
\text { an increased risk of hip fracture }\end{array}$ \\
\hline Trimpou et al ${ }^{192}$ & $\begin{array}{l}\text { Prospective study of male risk factors for } \\
\text { hip fracture-over } 30 \text {-years in } 7,495 \text { men }\end{array}$ & $\begin{array}{l}\text { A high degree of leisure time and physical } \\
\text { activity was protective }\end{array}$ \\
\hline
\end{tabular}


Table 3 Summary of prospective studies examining the association between body mass and hip fractures and showing equivocal results

\begin{tabular}{|c|c|c|}
\hline Authors & Study design & Conclusion \\
\hline Bean et $\mathrm{al}^{92}$ & $\begin{array}{l}\text { Prospective study of } 50 \text { consecutive women with } \\
\text { fractured hips and } 50 \text { age-matched healthy women } \\
\text { with no hip fractures }\end{array}$ & $\begin{array}{l}\text { After exclusion of heavily dependent patients, hip fracture was } \\
\text { not associated with reduced body mass or fat }\end{array}$ \\
\hline Ensrud et al'"I & $\begin{array}{l}\text { Prospective study of } 8,011 \text { women followed for incident } \\
\text { hip fracture }\end{array}$ & $\begin{array}{l}\text { During an average of } 5.2 \text { years, } 235 \text { ( } 2.9 \%) \text { experienced hip } \\
\text { fracture. Women with smaller body size had a higher risk of } \\
\text { subsequent hip fracture compared with those of larger body } \\
\text { size. This effect remained after adjusting for height, smoking } \\
\text { status, physical activity, health status, estrogen and diuretic } \\
\text { use. After further adjustment for femoral neck bone mineral } \\
\text { density, the effect of weight was negligible among thin women }\end{array}$ \\
\hline Mussolino et al ${ }^{107}$ & $\begin{array}{l}\text { Prospective population-based follow-up study for } \\
\text { maximum of } 22 \text { years of } 2,879 \text { white men }\end{array}$ & Weight loss is a risk factor for hip fracture in men \\
\hline Langlois et al ${ }^{108}$ & $\begin{array}{l}\text { Prospective study of } 2,413 \text { community-dwelling white } \\
\text { men aged } 67 \text { years or older }\end{array}$ & $\begin{array}{l}\text { Weight loss is a marker of frailty that may increase the risk of } \\
\text { hip fracture in older men }\end{array}$ \\
\hline Tromp et al ${ }^{199}$ & $\begin{array}{l}\text { Prospective study of } 348 \text { health women, aged } 70 \text { years } \\
\text { and above }\end{array}$ & Body mass index was found to be a predictor of hip fracture \\
\hline Margolis et $\mathrm{al}^{200}$ & $\begin{array}{l}\text { Prospective cohort study of } 8,059 \text { non black women } \\
65 \text { years and older over } 6.4 \text { years }\end{array}$ & $\begin{array}{l}\text { Women in the lowest quartile of weight had relative risks of } \\
2.0 \text { for hip fracture }\end{array}$ \\
\hline Langlois et al ${ }^{\prime 10}$ & $\begin{array}{l}\text { Prospective study of } 2180 \text { community-dwelling white } \\
\text { women aged } 50-74\end{array}$ & $\begin{array}{l}\text { Weight loss of } 10 \% \text { or more from maximum weight among } \\
\text { both middle-aged and older women is an important indicator } \\
\text { of hip fracture risk }\end{array}$ \\
\hline De Laet et al $^{109}$ & $\begin{array}{l}\text { Group studied } 60,000 \text { diverse men and women from } \\
12 \text { prospective population-based cohorts, with a total } \\
\text { follow-up of over } 250,0000 \text { person years }\end{array}$ & $\begin{array}{l}\text { Independent of age and gender, the contribution of body mass } \\
\text { index to a fracture risk was more marked at low levels of body } \\
\text { mass index than higher levels, although the relationship was } \\
\text { not linear }\end{array}$ \\
\hline Parker et al ${ }^{1 / 3}$ & $\begin{array}{l}\text { Prospective study of hip circumference and hip fractures } \\
\text { among } 30,652 \text { postmenopausal women }\end{array}$ & $\begin{array}{l}\text { Overall body size may be more important than body } \\
\text { composition of the femoral-gluteal area in the prediction } \\
\text { of hip fracture risk }\end{array}$ \\
\hline
\end{tabular}

mass and an increased fracture risk, ${ }^{106}$ especially among Caucasian men, ${ }^{107}$ after the age of 50 years, ${ }^{108}$ which may be amenable to intervention. This association is especially strong in individuals with low bone mineral density, ${ }^{109}$ and where a weight loss relative to maximal weight exceeds $10 \%$ of body weight. ${ }^{106,110}$ Moreover, older women with smaller body size are likely to be at high risk of fracturing their hips because of their potentially lower bone mineral density, ${ }^{111}$ as well as less soft tissue coverage of their hips than women of normal body weight. ${ }^{46,112}$

However, Parker and colleagues ${ }^{113}$ found overall body size, rather than body composition of the femoral gluteal area predicted the occurrence of a hip fracture in a cohort of postmenopausal women, and although most people who fracture their hips could be classified as being thin, Cumming and Klineberg ${ }^{114}$ and Maffulli and colleagues ${ }^{115}$ reported their patients with hip fractures tended to be overweight. Dretakis and Christadoulou ${ }^{116}$ too, noted similar rates of overweight and underweight hip fracture cases among their 373 patients.
Similarly, when patients with severe dementia were excluded, Bean and colleagues ${ }^{92}$ found thinness was not necessarily associated with hip fracture. Heavier individuals may also be expected to have low levels of sex hormone-binding globulin, a prevalent finding among women with recent hip fractures, ${ }^{117}$ and several comorbid conditions that are known risk factors for falling, plus medical conditions associated with osteoporosis. ${ }^{118}$

\section{Bone structure}

Although hip fracture is the most serious consequence of osteoporosis, ${ }^{119}$ the literature is inconsistent in demonstrating diminished bone density is universally predictive of a future hip fracture. For example, while bone density measures at the femoral neck were found to be strongly predictive of hip fractures in both men and women in one study, ${ }^{120}$ several others have reported a considerable overlap in bone densities between hip fracture patients and age- and gender-matched controls after the age of 70 years, or no 
significant risk. ${ }^{87-89,93}$ In addition, Wei and colleagues ${ }^{119}$ found the effect of significant risk factors for hip fracture of direct hip impact, previous stroke, sideways fall, decreased functional mobility, or low body mass remained the same regardless of femoral neck bone density. However, bone mineral density was significantly correlated with functional mobility and low body mass, which together are predictive of falls that can result in hip fractures. It has also been observed that bone mineral density is a weaker predictor of intertrochanteric hip fractures than femoral neck fractures. ${ }^{121}$ Other data reveal comparable osteoporotic indices between cases and controls, ${ }^{122}$ and that hip fracture cases were not more osteopenic than age- and gender-matched controls. ${ }^{123}$ Moreover, Asians, who have similar, or lower bone mineral densities than Caucasians, and partake in diets low in calcium, have a low incidence rate of hip fracture, especially in women. ${ }^{14}$ Mathematical models too, cannot account for the exponential rise in hip fractures with age solely on the basis of bone density levels. ${ }^{124}$ Further, individuals with osteoarthritis and higher bone density levels than the norm are not protected against hip fractures. ${ }^{125}$

Such findings strongly suggest factors other than low bone mineral density and bone mass contribute to the risk of hip fractures. These factors include but are not limited to those that increase the risk for falling, the property of the fall surface, the geometry of the hip, body size, the degree of soft tissue coverage around the hip, and the presence of poor muscle responsiveness and muscle weakness ${ }^{46,85,93,97,113,114,122}$ (see Table 4).

\section{Clinical}

\section{Chronic health conditions}

Many chronic illnesses associated with aging, in particular, arthritis and Parkinson's disease, substantially increase the risk of falling, and hence the likelihood of incurring a hip fracture. ${ }^{126-128}$ In addition, arrhythmias, postural hypertension, and peripheral neuropathies may increase the risk of falls and hip fractures ${ }^{67}$ as may the presence of Alzheimer's disease ${ }^{129}$ and other neurological conditions, such as stroke. ${ }^{130}$ Diabetes mellitus, ${ }^{131}$ hyperthyroidism, ${ }^{132}$ and medical conditions associated with osteoporosis, ${ }^{133}$ other forms of disability associated with the risk of falling, ${ }^{133}$ use of walking aids, ${ }^{134}$ as well as prolonged immobilization, ${ }^{46}$ may also increase the risk of sustaining a hip fracture. Rehospitalization after hip fracture may also be influenced negatively by the presence of comorbid clinical problems, ${ }^{135}$ as may outcomes of acute hip fracture if multiple problems exist, especially respiratory disease or malignancy. ${ }^{136}$
Table 4 Selected studies covering a 20 year period describing hip fracture injury risk factors other than bone mineral density and bone mass that could serve as risk assessment and risk reduction intervention points

\begin{tabular}{|c|c|}
\hline Author & Factors influencing hip fracture \\
\hline Cummings and Nevitt 124 & Neuromuscular dysfunction \\
\hline Cummings and Nevitt ${ }^{201}$ & Fall mechanics \\
\hline Wolinsky and Fitzgerald ${ }^{202}$ & Prior falls; Low body weight \\
\hline Jones et al ${ }^{203}$ & Postural instability \\
\hline Parker et $\mathrm{al}^{204}$ & Environmental factors \\
\hline Slemenda ${ }^{85}$ & Neuromuscular impairment; Fall mechanics \\
\hline Dargent-Molina et $\mathrm{al}^{97}$ & Walking speed; Impaired mobility \\
\hline Fitzpatrick et al ${ }^{122}$ & $\begin{array}{l}\text { Factors related to falls; Sleeping tablets; } \\
\text { Lower mental health score }\end{array}$ \\
\hline Holmberg et $\mathrm{al}^{60}$ & Diabetes; Poor self-rated health status \\
\hline Wilson et al ${ }^{59}$ & $\begin{array}{l}\text { Health insurance status; Education; } \\
\text { Residence }\end{array}$ \\
\hline Abrahamsen et al ${ }^{18}$ & $\begin{array}{l}\text { Prostate cancer and Androgen derivation } \\
\text { therapy }\end{array}$ \\
\hline Kulmala et $\mathrm{al}^{77}$ & Balance confidence; Functional balance \\
\hline Chen et $\mathrm{al}^{205}$ & $\begin{array}{l}\text { Breast/other cancers in postmenopausal } \\
\text { women }\end{array}$ \\
\hline Formigo et a $\left.\right|^{182}$ & $\begin{array}{l}\text { Recurrent falls in past year; Poor functional } \\
\text { status; Use multiple drugs, neuroleptics }\end{array}$ \\
\hline Tafuri et al ${ }^{206}$ & $\begin{array}{l}\text { Work related factors for males; home } \\
\text { accidents for females }\end{array}$ \\
\hline Piirtola et al ${ }^{171}$ & Proximal humeral fractures \\
\hline Collins et $\mathrm{al}^{207}$ & Peripheral arterial disease in men \\
\hline \multirow[t]{2}{*}{ Stolee et a $\left.\right|^{188}$} & $\begin{array}{l}\text { Older age; Female gender; Falls; Unsteady } \\
\text { gait; Use of ambulatory aide; }\end{array}$ \\
\hline & $\begin{array}{l}\text { Tobacco use; Severe malnutrition; Cognitive } \\
\text { impairment }\end{array}$ \\
\hline Wolinsky et $\mathrm{al}^{208}$ & Recent hospitalization for non-hip fracture \\
\hline Sahni et a ${ }^{209}$ & Inadequate supplemental levels of Vitamin C \\
\hline Kristensen et $\mathrm{al}^{210}$ & Knee extension strength \\
\hline
\end{tabular}

\section{Impaired cognition}

In addition to the aforementioned factors, depression, and/or the presence of one or more cognitive impairments may heighten the risk of falling and fracturing a hip. . $4,126,128,135,137-139,144-146^{-14}$ Similarly, a prevailing cognitive impairment may impact the effectiveness of postoperative rehabilitation strategies after hip fracture surgery, ${ }^{140}$ and increases the risk of falling after a hip fracture. ${ }^{141}$ The individual with mental deterioration who trips and fails to break their fall may be especially vulnerable to fracturing the hip if already weak and osteoporotic due to poor nutritional status. ${ }^{142}$

\section{Impaired vision}

Impaired vision may be an independent risk factor for hip fracture. ${ }^{83,126,143}$ Evidence for this has been provided by 
Ivers and colleagues in a prospective study of 3,654 adults aged 49 years or older for five years ${ }^{143}$ and by Ivers and colleagues $^{144}$ in a case-control study of 911 cases and 910 controls aged 60 years or older. In the latter study, the population attributable risk of hip fracture due to poor visual acuity or stereopsis, vision wherein two separate images from two eyes are successfully combined into one image in the brain, was $40 \%$. In their more recent prospective study, Ivers and colleagues found visual impairment to be strongly associated with risk of hip fracture in the next two years. Pfister and colleagues ${ }^{145}$ also noted impaired vision was prevalent among women aged 50 years and older with proximal hip fractures. Impaired vision has also been associated with hip fractures occurring in the hospital ${ }^{146}$ and among the Framingham Study Cohort, ${ }^{147}$ where those with poor vision in one or both eyes had an elevated fracture risk and those with moderately impaired vision in one eye and good vision in the other had a higher risk of fracture than those with a similar degree of binocular impairment.

\section{Medications, alcohol, and chemical substances}

Although Rashiq and Logan, ${ }^{148}$ who examined the role of drugs in hip fractures found that with the exception of antibiotics, fracture risk was lower in those taking drugs, drugs reported to be related to falls that may lead to a hip fracture include: cimetidine, psychotropic anxiolytic/hypnotic drugs, barbiturates (which may also decrease bone quality), opioid analgesics, and antihypertensives, ${ }^{126,137}$ long-acting benzodiazepines, anticonvulsants, and caffeine. ${ }^{89}$ Tranquillizers, sedatives, and exposure to any of the three classes of antidepressants is associated with a significant increase in the risk of falling and sustaining a hip fracture. ${ }^{66,67,149}$ In particular, long-acting sedatives and alcohol that can slow reaction time may partly explain the increased risk of hip fractures associated with use of sedatives and regular alcohol intake. ${ }^{124,136,134}$ Alternately, alcohol abuse may result in a negative bone balance, ${ }^{150}$ decreased balance, impaired gait, and heightened risk-taking behaviors. ${ }^{151}$ Additionally, tricyclic antidepressants may increase the risk for hip fracture due to their detrimental cardiovascular side-effects, and/or their side-effects of sedation and confusion. ${ }^{152}$ Use of corticosteroids is also a documented risk factor for hip fracture, ${ }^{46}$ and may reflect the detrimental effect of corticosteroids on bone mineral density, as may levothyroxine when used by males. ${ }^{153}$ Smoking cigarettes or a pipe, ${ }^{98}$ and the consumption of tea, and fluorine concentrations over $0.11 \mathrm{mg}$ per liter ${ }^{154}$ also increases the risk of hip fracture, ${ }^{17,98}$ as do benzodiazepines. ${ }^{155}$

\section{Environmental factors}

Although many preventive programs against hip fracture focus on environmental factors, of the many factors that can influence hip fracture risk, Norton and colleagues ${ }^{156}$ found only $25 \%$ of falls that could lead to a hip fracture were associated with an environmental hazard. Further, while environmental factors may undoubtedly be a precursor to injurious falls ${ }^{157}$ a study by Allander and colleagues ${ }^{158}$ found a very low correlation between the number of risk factors of the faller and the environment.

In summary, age, a variety of age-associated physiological changes, low levels of physical activity participation, poor nutrition practices, and some forms of medication may impact two crucial determinants of hip fracture, namely femoral bone strength, and the propensity to falls. In addition, declining muscle, cognitive, visual and neural reflex responses, are likely to impact the propensity of older adults towards hip fracture injuries. ${ }^{45}$ The overlapping relationship between these factors as portrayed in Figure 1 are also likely to impact recurrent falls, and second or new hip fractures following a hip fracture ${ }^{159}$ and may also explain partly why hip fracture incidence rates vary, and remain substantive in many regions (see Table 5).

Conversely, a better understanding of these factors may help in reducing the persistent and debilitating outcomes of hip fracture injuries portrayed in Table 6 .

\section{Discussion}

As outlined in the body of the paper, despite some successes in reversing predicted hip fracture trends in some regions, many current reports continue to describe increasing or rising hip fracture trends in other regions (see Table 4). Although it is consequently impossible to determine if the projected global incidence of hip fracture cases is likely to reach 4.5 million by 2050 as predicted, ${ }^{4}$ it seems fair to anticipate increases in some regions.

For example, hip fracture incidence rate increases, rather than decreases are expected in Asia, Latin America, the Middle East, and Africa as a result of increases in their elderly populations. ${ }^{16}$ Similarly, hip fractures in people aged 60 years and older living in central Australia are predicted to almost double by 2011 and increase 2.5-fold and 5.4-fold by 2021 and 2051, respectively. ${ }^{160}$ A current Norwegian study has further revealed regions of the country where high lifetime absolute fracture risk rates among adults aged 25 years and older are predicted based on 1995-2004 data. ${ }^{161}$ Another related report showed annual decreases in New York State between 1985 and 1996 were not uniform in all age, gender, 


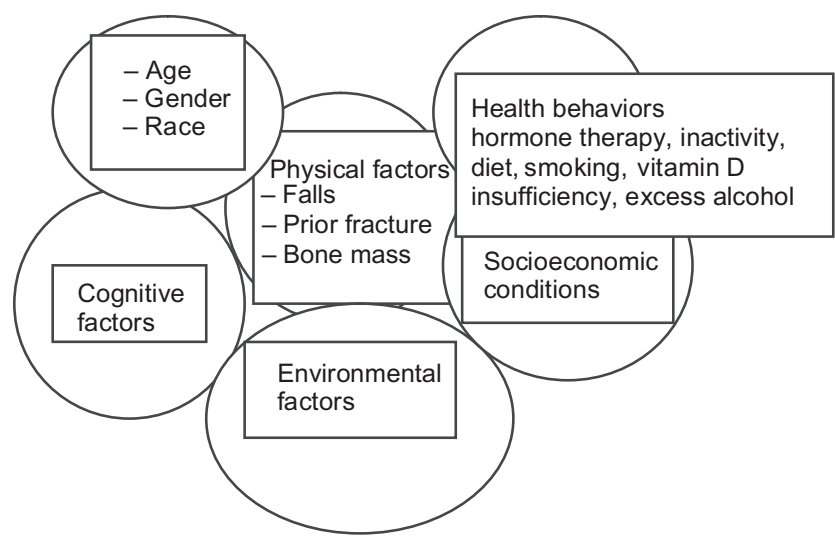

Figure I Model of key factors implicated in hip fracture injury with intervention points highlighted.

Source: Kanis, Johansson, Oden, et al. ${ }^{189}$

and race groups. ${ }^{162}$ In addition, in 2008, Auron-Gomez and ${ }^{163}$ from the Cleveland Clinic stated the incidence of hip fractures in the United States of approximately 250,000 per year is expected to double in 30 years.

Moreover, as outlined by Abrahamsen and colleagues ${ }^{164}$ and summarized in Table 5, even in regions where hip fracture rates are declining, the very stark human impact of sustaining one or more hip fractures supports a continued global effort to minimize this burden. As well, the economic consequences of hip fracture continue to rise, despite declining lengths of hospital stay. ${ }^{66}$

However, because many variations in hip fracture prevalence rates exist, and multiple, rather than single risk factors preside interventions to reduce their prevalence are difficult to develop without further research. ${ }^{44}$ In addition, the correlation between hip fractures and low bone density is not a perfectly positive one, ${ }^{165}$ and thus more insightful studies to better elucidate the etiology of hip fracture variants is indicated as outlined almost 20 years ago by Cummings and Nevitt. ${ }^{124}$ In this regard, as Leibson and colleagues ${ }^{64}$ have pointed out, hip fracture prophylaxis and its potential savings may be overestimated by studies that fail to consider differential risk, mortality and long-term follow-up data. Moreover, even though Chang and colleagues ${ }^{166}$ emphasized the need for early osteoporosis prevention in both men and women because over $48 \%$ of hip fractures in men and $66 \%$ of those in a white population in Australia were found to incur hip fractures before the ages of 80 and 85 years, respectively, Lippuner and colleagues ${ }^{63,64}$ note there is a significant lack of awareness of this disease and its consequences and this warrants attention. In addition, there are few carefully designed prospective studies that examine the nature of the age-specific increase in incidence, and whether this is due to changes in the etiology of the fracture, and not just the consequence of demographic change as postulated by Boyce and Vessey in 1985. ${ }^{167}$

What is known, is that to prevent unwarranted increases in hip fracture incidence rates and their secondary complications and costs, careful consideration of their multifactorial causation is imperative. ${ }^{3,36,162,168}$ Other promising strategies include the development of routine risk-factor assessments

Table 5 Contemporary studies that show evidence of rising hip fracture incidence rates in a number of venues worldwide, despite declining rates in others

\begin{tabular}{|c|c|c|}
\hline Study & Location & Finding \\
\hline Sanders et $\mathrm{al}^{28}$ & Australia & Hip fractures rates were projected to increase $36 \%$ over next few decades \\
\hline Hagino et $\mathrm{al}^{211}$ & Tottori Prefecture, Japan & Hip fracture rates increased from 1986-200I for both genders \\
\hline Hernadez et $\mathrm{al}^{212}$ & Northern Spain & Crude incidence increased $50 \%$ from 1988-2002, mainly in women, and for cervical sites \\
\hline Giversen $^{213}$ & Denmark & Age-adjusted hip fracture rates increased between 1987-97 and was 425 per 1000,000 in 1997 \\
\hline Lonnroos et al ${ }^{124}$ & Finland & The total number of hip fractures increased by $70 \%$ from $1992-93$ to $2002-03$ \\
\hline Lim et $\mathrm{al}^{43}$ & Korea & Population based data from $200 \mathrm{I}-2004$ showed rates increased for women, not men \\
\hline Mann et $\mathrm{al}^{29}$ & Austria & There was no leveling-off or downward trend in hip fracture rates from 1994-2006 \\
\hline Tafuri et $\mathrm{al}^{206}$ & Puglia, Italy & Yearly admission rates from 1998-2005 for femoral neck fractures increased \\
\hline lcks et $\mathrm{al}^{215}$ & Germany & $\begin{array}{l}\text { Between 1995-2004 hip fracture incidence increased only slightly, especially among older ages, } \\
\text { and men }\end{array}$ \\
\hline Shao et al ${ }^{194}$ & Tainan, Taiwan & $\begin{array}{l}\text { Overall incidence of hip fractures increased by } 30 \% \text { between } 1996-2002 \text {, with greater increases } \\
\text { in males }\end{array}$ \\
\hline Holt et $\mathrm{al}^{216}$ & Scotland & $\begin{array}{l}\text { The number of hip fractures is predicted to rise by } 45 \%-75 \% \text { between } 2004-203 \text { I, especially in } \\
\text { those }>85\end{array}$ \\
\hline Dodds et $\mathrm{al}^{217}$ & Ireland & $\begin{array}{l}\text { Annual hip fracture numbers are expected to increase by } 100 \% \text { by } 2026 \text {, assuming stable } \\
\text { incidence rates }\end{array}$ \\
\hline
\end{tabular}


Table 6 Chronology of studies over a 20 year period consistently describing poor outcomes after hip fracture, regardless of contemporary management and rehabilitation strategies

\begin{tabular}{ll}
\hline Authors & Hip fracture population \\
\hline Jette et $\mathrm{al}^{218}$ & 50 cases with intertrochanteric fractures, \\
25 cases with subcapital hip fractures, mea \\
age 78 years \\
I5 I community-dwelling elders \\
Bonar et $\mathrm{al}^{219}$ & 185 cases mean age 80 years treated by \\
Jalovaara and Virkkunen ${ }^{220}$ & $\begin{array}{l}\text { cementless hemiarthroplasty for acute } \\
\text { femoral fractures }\end{array}$
\end{tabular}

$\begin{array}{ll}\text { Marottoli et } \mathrm{al}^{221} & 120 \text { cases } \\ \text { Parker and Palmer } & \end{array}$

Aharonoff et al $^{222}$

Stavrou et al ${ }^{176}$

Wolinsky et $\mathrm{al}^{223}$

Koike et $\mathrm{al}^{224}$

Giaquinto et $\mathrm{a}^{225}$

Maggio et $\mathrm{al}^{226}$

Davidson et al $^{174}$

Van Balen et $\mathrm{al}^{227}$

Kirke et $\mathrm{al}^{228}$

Roche et $\mathrm{al}^{136}$

De Luise $C^{178}$

Haleem et $\mathrm{al}^{3}$
612 elderly who had sustained non-pathologic hip fractures

202 cases with femoral neck or trochanteric fractures, ages 52-95

368 cases and controls

I 14 cases

58 cases, mean age 86.7 years

42 cases

33 I cases

Prospective study of 102 elderly hip fracture patients mean age 83 years

Prospective 2 year follow up of 106 older Irish women with hip fracture histories and 89 without hip fracture

\section{8 consecutive cases}

I.4 million inhabitants of Western Denmark was the population. All persons over 40 with first hip fractures were identified between 1998-2003

Reviewed all articles on outcome of hip fracture between 1959 and 1998
Key findings concerning mortality and morbidity

29 percent died in first year, only 21 percent regained pre-fracture function in 6 instrumental activities of daily living; 26 percent regained their pre-fracture level of social/role functioning

64 percent were discharged home within 6 months, 33 percent became permanent nursing home residents

There were 22 early complications, and 6 late complications; mortality after at 3 months was 12 percent above controls, 19 percent at 12 months and 21 percent at 18 months; the average loss of life in the fracture group compared to the control group was 425 days

18 percent died within 6 months, 35 percent were institutionalized within 6 months

Mortality at one year was 22 percent; 14 percent were in longterm residential care; and the remaining 65 percent were living at home

4 percent died during hospitalization, 12.7 percent died within one year of fracture

18 percent died during first year; mortality was greater in patients with cardiorespiratory diseases, and if operation was delayed 3 days, or if hemiarthroplasty was performed

Hip fracture increased the likelihood of mortality in the first 6 months postfracture significantly; it also increased the likelihood of subsequent hospitalization, and number of days in hospital

The mortality rate after one year was 18 percent, which was 2.5 times larger than the general population

12 patients died after complications of previous risk factors, on average survivors showed functional gains from admission to discharge, but most required supervision at discharge

The percentage of residents ambulating autonomously fell from 95-32 percent among those with fractures even though their pre-fracture mobility status was better than those who never fractured their hips

|2-month mortality was 26 percent. Follow-up of 23 | surviving patients 12-24 months later showed 27 percent still had pain and 60 percent had worsened mobility

Mortality at 4 months was 20 percent, only 57 percent survivors returned to original accommodations, 43 percent achieved prior walking ability, 17 percent achieved prior daily living abilities, quality of life at 4 months was worse than reference population Mortality at I year was 16 percent, and 23.6 percent at 2 years. This occurred even though males or subjects with moderate or severe mental impairment were not included in the study. Hip fracture had a marked negative effect on functional independence Mortality was 9.6 percent at 30 days, and 33 percent at one year After approximately 22 months, persons with hip fracture had 2-3 times higher odds of death at lyear compared to controls. Comorbid health conditions increased chance of dying by $50 \%$ at I-year, including congestive heart failure, dementia, tumor, and pulmonary disease

The mortality rates and 6 and 12 months remained essentially unchanged over the 4 decades, being II-23 percent at 6 months, 22-29 percent at I year 
for older adults, ${ }^{169}$ improved study designs that examine the predictive role of novel factors in mediating hip fractures, ${ }^{40}$ the reduction of remediable visual, hearing, and combined impairments among aging cohorts, ${ }^{170}$ and encouraging the avoidance of excessive alcohol, and psychotic drugs among people at risk for first or second hip fractures. Factors that may be especially useful to examine regularly during annual check ups are listed in Box 1 and others warranting attention include those potential predictors outlined by Wilson and colleagues ${ }^{59}$ such as health insurance status, and educational level.

In the context of preventing secondary disability and poor outcomes, careful analyses of the type of fracture involved,

Box I Possible screening interventions that could be applied routinely in primary care or community settings during regular examinations and among those receiving surgical interventions for a first hip fracture to offset primary and secondary hip fractures and poor outcomes

I. Examine:
Balance capacity
Bone density
Cognitive status
Drug usage, medications such as steroids
Presence of comorbid conditions
Falls history
Overall health and nutritional status
Lifestyle, nutritional practices, and activity levels
Muscle strength and reflex responsiveness
Proprioception
Tobacco usage
Walking ability
Vision
Homocysteine levels
II. Do careful follow-up of proximal humeral fracture cases ${ }^{230}$
III. Identify older adults at risk for falls due to:
- Fear of falling
- Poor housing
- Lack of activity opportunities
- Poor nutrition
- Unstable or poor mental status
- Adventional distress ${ }^{164}$
- Alcohol problem housing or environment
- Age
-

the etiology of the fracture, and the appropriate timing of tailored interventions may be crucial. ${ }^{160,171}$ Identifying risk factors that explain gender differences in risk and outcome, ${ }^{171}$ as well regional variations could potentially impact hip fracture incidence rates as well. ${ }^{162}$ Examining the role of the health care system in the context of explaining hip fracture variants and the prevailing degree of health or disability may also be helpful.

In summary, because hip fracture risk rises exponentially with age, ${ }^{44,172}$ hip fractures are likely to remain an important public health problem despite declining incidence trends in some regions. ${ }^{159}$ Indeed, high numbers of aging adults will continue to be impacted globally by this injury, ${ }^{160,173}$ because by 2031 approximately $45 \%$ of all hip fracture cases will be aged 85 years or older. ${ }^{164}$

As well, regardless of progress in reducing hip fracture incidence in some regions, high levels of disability among survivors persists, and a high proportion of hip fracture cases, particularly men ${ }^{174,175}$ and those older than 75 years, continue to die at increased rates within the first three to six months of their injury. ${ }^{171}$ Those with comorbidities, ${ }^{140,175,176,178}$ and poor mental status - which are likely to continue to be consistent features among aging populations - are especially vulnerable. ${ }^{133,178}$ Other factors that predict poor post-hip fracture outcomes are less than optimal follow-up of survivors, ${ }^{179}$ limited prefracture mobility, ${ }^{180-182}$ a variety of psychosocial factors, ${ }^{183}$ the patient's general medical condition, ${ }^{184,178}$ balance status, ${ }^{185}$ their propensity towards falling, ${ }^{186}$ and eye and neurological diseases. ${ }^{187}$

To offset the predicted hip fracture burden, ${ }^{35}$ careful study of hip fracture variants, ${ }^{164}$ collecting and carefully analyzing routinely collected data ${ }^{188}$ for evidence of clinical risk factors other than bone mineral density, ${ }^{165,189}$ establishing a standard method for determining hip fracture incidence, ${ }^{50}$ and more vigilance in secondary prevention contexts is recommended. ${ }^{3}$ As well, more epidemiological studies to elucidate trends in hip fracture occurrences due to demographics, age, gender, ethnicity, ${ }^{6}$ health care setting, ${ }^{168,190}$ and health care system diversity $^{166}$ are desirable. Public health organizations in developing countries are especially encouraged to develop innovative preventive strategies, ${ }^{191}$ and high risk adults, especially those with comorbid diseases, ${ }^{178}$ low body mass and low income, ${ }^{192}$ and elders in institutions at high risk for first and second hip fractures, excess mortality and poor outcomes, ${ }^{168,171,190,193}$ should be targeted. ${ }^{50}$ In addition, men who appear increasingly vulnerable to hip fracture ${ }^{43}$ should be targeted. ${ }^{194}$ Aging adults should have access to timely preventive strategies, ${ }^{159}$ including osteoporosis prevention, ${ }^{166}$ 
and be encouraged to maintain physically active lifestyles, and appropriate body weights. ${ }^{19,195}$

\section{Disclosure}

The author reports no conflicts of interest in this work.

\section{References}

1. Leslie WD, O'Donnell S, Jean S, et al; Osteoporosis Surveillance Expert Working Group. Trends in hip fracture rates in Canada. JAMA. 2009;302:883-889.

2. Nieves JW, Bilezikian JP, Lane JM, et al. Fragility fractures of the hip and femur: incidence and patient characteristics. Osteoporos Int. 2009 May 30; [Epub ahead of print].

3. Haleem S, Lutchman L, Mayahi R, Grice JE, Parker MJ. Mortality following hip fracture: trends and geographical variations over the last 40 years. Injury. 2008;39:1157-1163.

4. Parker M, Johansen A. Clinical review. Hip fracture. BMJ. 2006;333: $27-30$.

5. Guilley B, Chevally T, Herrmann F, et al. Reversal of the hip fracture secular trend is related to a decrease in the incidence in institution dwelling elderly women. Osteoporos Int. 2008;19:1741-1747.

6. Wehren LE, Magaziner J. Hip fracture: risk factors and outcomes. Curr Osteoporos Reports. 2003;1:78-85.

7. Samelson EJ, Zhang Y, Kiel DP, Hannan MT, Felson DT. Effect of birth cohort on risk of hip fracture: age-specific incidence rates in the Framingham Study. Am J Public Health. 2002;92:858-862.

8. Wilson RT, Wallace RB. Trends in hip fracture incidence in young and older adults. Am J Public Health. 2007;97:1734-1735.

9. Scott JC. Osteoporosis and hip fractures. Rheum Dis Clin North Am. 1990;16:717-740

10. Clark P, Lavielle P, Franco-Marina F, et al. Incidence rates and life-time risk of hip fractures in Mexicans over 50 years of age: a populationbased study. Osteoporos Int. 2005;16:2025-2030.

11. Demontiero O, Duque G. Once-yearly zoledronic acid in hip fracture prevention. Clin Interv Aging. 2009;4:153-164.

12. Lyons AR. Clinical outcomes and treatment of hip fractures. Am J Med. 1997;103:51S-64S.

13. Suzman RM. The Older Old. New York, NY: Oxford University Press; 1992.

14. Yan L, Zhou B, Prentice A, Wang X, Golden MHN. Epidemiological study of hip fracture in Shenyang, People's Republic of China. Bone. 1999;24:151-155.

15. Xu L, Lu A, Zhao X, Chen X, Cummings SR. Very low rates of hip fracture in Beijing, People's Republic of China. The Beijing Osteoporosis project. Am J Epidemiol. 1996;144:901-907.

16. Kannus P, Parkkari J, Sievanen H, et al. Epidemiology of hip fractures. Bone. 1996;18:57S-63S.

17. Kannus P, Niemi S, Parkkari J, Palvanen M, Vuori I, Jarvinen M. Hip fractures in Finland between 1970 and 1997 and predictions for the future. Lancet. 1999;353:802-805.

18. Boereboom FT, Raymakers JA, de Groot RR, Duursma SA. Epidemiology of hip fractures in the Netherlands: women compared with men. Osteoporosis Int. 1992;2:279-284.

19. Hagino H. Muscle and bone health as a risk factor of fall among the elderly. Epidemiology of falls and fractures. Clin Calcium. 2008; 18:747-753.

20. Jarnlo GB. Hip fracture patients. Background factors and function. Scandinav J Rehabil Med. 1991;Suppl 24:1-31.

21. Melton LJ III, Kearns AE, Atkinson EJ, et al. Secular trends in hip fracture incidence and recurrence. Osteoporosis Int. 2009;20: 687-694.

22. Chevalley T, Guilley E, Herrmann FR, Hoffmeyer P, Rapin CH, Rizzoli R. Incidence of hip fracture over a 10-year period (1991-2000): reversal of a secular trend. Bone. 2007;40:1284-1289.
23. Cooper C, Campion G, Melton LJ. Hip fractures in the elderly: a worldwide projection. Osteoporos Int. 1992;2:285-289.

24. Looker AC, Melton LJ, Harris TB, Borrud LG, Shepherd JA. Prevalence and trends in low femur bone density among older US adults: NHANES 2005-2006 compared with NHANES III dagger. J Bone Miner Res. $2009 \mathrm{Jul} 6$; [Epub ahead of print].

25. Reginster JY, Gillet $P$, Gosset C. Secular increase in the incidence of hip fractures in Belgium between 1984 and 1996: need for a concerted public health strategy. Bull World Health Org. 2001;79: 942-946.

26. Gullberg B, Johnell O, Kanis JA. Worldwide projections for hip fracture. Osteoporos Int. 1997;7:407-413.

27. Konnopka A, Jerusel N, König HH. The health and economic consequences of osteopenia- and osteoporosis-attributable hip fractures in Germany: estimation for 2002 and projection until 2050. Osteoporos Int. 2009;20:1117-1129.

28. Sanders KM, Nicholson GC, Ugoni AM, Pasco JA, Seeman E, Kotowicz MA. Health burden of hip and other fractures in Australia beyond 2000. Projections based on the Geelong Osteoporosis study. Med J Aust. 1999;170:467-470.

29. Mann E, Icks A, Haastert B, Meyer G. Hip fracture incidence in the elderly in Austria: an epidemiological study covering the years 1994 to 2006. BMC Geriatr. 2008;8:35.

30. Lark MW, James IE. Novel bone antiresorptive approaches. Curr Opinion Pharmacol. 2002;2:330-337.

31. Huusko TM, Karppi P, Avikainen V, Kautiainen H, Sulkava R. The changing picture of hip fractures: dramatic change in age distribution and no change in age-adjusted incidence within 10 years in central Finland. Bone. 1999;24:257-259.

32. Lau EM, Cooper C, Fung H, Lam D, Tsang KK. Hip fracture in Hong Kong over the last decade-a comparison with the UK. J Public Health Med. 1999;21:249-250.

33. Alvarez-Nebreda ML, Jimenez AB, Rodriguez P, Serra JA. Epidemiology of hip fracture in the elderly in Spain. Bone. 2008;42:278-285.

34. Paspati I, Galanos A, Lyritis GP. Hip fracture epidemiology in Greece during 1977-1992. Calc Tissue Int. 1998;62:542-547.

35. Lyritis GP. Epidemiology of hip fracture: the MEDOS study. Osteoporos Int. 1996;Suppl 3:S11-S15.

36. Melton LJ. Epidemiology of hip fractures: implications of the exponential increase with age. Bone. 1996;18:121S-125S.

37. Hiebert R, Aharonoff GB, Capla EL, et al. Temporal and geographic variation in hip fracture rates for people aged 65 or older, New York State, 1985-1996. Am J Orthop. 2005;34:252-255.

38. Espino DV, Silva Ross J, Oakes SL, Becho J, Wood RC. Characteristics of hip fractures among hospitalized elder Mexican American Black and White Medicare beneficiaries in the Southwestern United States. Aging Clin Exp Res. 2008;20:344-448.

39. Koh LK, Saw SM, Lee JJ, Leong KH, Lee J. Hip fracture incidence rates in Singapore 1991-1998. Osteoporos Int. 2001;12:311-318.

40. Vestergaard P, Rejnmark L, Mosekilde L. Strongly increasing incidence of hip fractures in Denmark from 1977 to 1999. Ugeskr Laeger. 2008; 18:621-623.

41. Fielden J, Purdie G, Horne G, Devane P. Hip fracture incidence in New Zealand, revisited. N Z Med J. 2001;13:154-156.

42. Löfman O, Berglund K, Larsson L, Toss G. Changes in hip fracture epidemiology: redistribution between ages, genders and fracture types. Osteoporos Int. 2002;13:18-25.

43. Lim S, Koo BK, Lee EJ, et al. Incidence of hip fractures in Korea. J Bone Miner Metab. 2008;26:400-405.

44. Memon A, Pospula WM, Tantawy AY, et al. Incidence of hip fracture in Kuwait. Int J Epidemiol. 1998;27:860-865.

45. Boonen S, Broos P, Dequeker J. Age-related factors in the pathogenesis of senile (Type II) femoral neck fractures. An integrated view. Am J Orthop. 1996;25:198-204.

46. Lau EM, Lee Jk, Suriwongpaisal P, et al. The incidence of hip fracture in four Asian countries; the Asian Osteoporosis Study (AOS). Osteoporos Int. 2001;12:239-243. 
47. Lauderdale DS, Jacobsen SJ, Furner SE, et al. Hip fracture incidence among elderly Asian-American populations. Am J Epidemiol. 1997; 15:502-509.

48. Fisher AA, OBrien ED, Davis MW. Trends in hip fracture in Australia: possible impact of bisphosphonates and hormone replacement therapy. Bone. 2009;45:246-253.

49. Finsen V, Johnsen LG, Tranø G, Hansen B, Sneve KS. Hip fracture incidence in central Norway: a followup study. Clin Orthop Relat Res. 2004;419:173-178.

50. Cerwinski E, Kanis JA, Trybulec B, Johansson H, Borowy P, Osieleniec J. The incidence and risk of hip fracture in Poland. Osteoporosis Int. 2009;20:1363-1367.

51. Duboeuf F, Hans D, Schott AM, et al. Different morphometric and densitometric parametrs predict cervical and trochanteric hip fracture: the EPIDOS Study. J Bone Miner Res. 1997;12:1895-1902.

52. Michelson JD, Myers A, Jinnah R, Cox Q, Van Natta M. Epidemiology of hip fractures among the elderly. Risk factors for fracture type. Clin Orthop Rel Res. 1995;311:129-135.

53. Levy AR, Mayo NE, Grimard G. Rates of transcervical and pertrochanteric hip fractures in the province of Quebec, Canada, 1981-1992. Am J Epidemiol. 1995;142:428-436.

54. Cauley JA, Lui LY, Genant HK, et al; Study of Osteoporotic Fractures Research and Group. Risk factors for severity and type of the hip fracture. J Bone Miner Res. 2009;24:943-955.

55. Fox KM, Magaziner J, Hebel JR, Kenzora JE, Kashner TM. Intertrochanteric versus femoral neck hip fractures: differential characteristics, treatment and sequelae. J Gerontol A Biol Sci Med Sci. 1999;54: M635-M640.

56. Keene GS, Parker M, Pryor GA. Mortality and morbidity after hip fractures. BMJ. 1993;307:1248-1250.

57. Martinez AA, Cuenca J, Panisello JJ, et al. Changes in the morphology of hip fractures within a 10-year period. J Bone Min Metab. 2001;19: 378-381.

58. Karagas MR, Lu Yao GL, Barrett JA, Beach ML, Baron JA. Heterogeneity of hip fracture: age, race, sex, and geographic patterns of femoral neck and trochanteric fractures among the US elderly. Am J Epidemiol. 1996;143:677-682.

59. Wilson RT, Chase GA, Chrischilles EA, Wallace RB. Hip fracture risk among community-dwelling elderly people in the United States a prospective study of physical, cognitive, and socioeconomic indicators. Am J Public Health. 2006;96:1210-1218.

60. Holmberg AH, Johnell O, Nilsson PM, Nilsson J, Berglund G, Akesson K. Risk fractures for hip fractures in a middle-aged population: a study of 33,000 men and women. Osteoporos Int. 2005;16 2185-2194.

61. Cummings SR, Melton LJ. Epidemiology and outcomes of osteoporotic fractures. Lancet. 2002;359:1761-1767.

62. Koeck CM, Schwappach DL, Niemann FM, et al. Incidence and costs of osteoporosis-associated hip fractures in Austria. Wien Klin Wochensch. 2001;113:371-377.

63. Lippuner K, Golder M, Greiner R. Epidemiology and direct medical costs of osteoporotic fractures in men and women in Switzerland. Osteoporos Int. 2005;16 Suppl 2:S8-S17.

64. Leibson CL, Tosteson AN, Gabriel SE, Ransom JE, Melton LJ. Mortality, disability, and nursing home use for persons with and without hip fracture: a population-based study. J Am Geriatr Soc. 2002;50: 1644-1650.

65. Hayes WC, Myers ER, Robinovitch SN, Van Den Kroonenberg A. Etiology and prevention of age-related hip fractures. Bone. 1996;18: 77S-86S.

66. Gehlbach SH, Avrunin JS, Puleo E. Trends in hospital care for hip fractures. Osteoporos Int. 2007;18:585-591.

67. Azhar A, Lim C, Kelly E, et al. Cost induced by hip fractures. Ir Med J. 2008;101:213-215.

68. Cumming RG, Klineberg R, Katelaris A. Cohort study of risk of institutionalisation after hip fracture. Aust N Z J Public Health. 1996; 20:579-582.
69. Melton LJ 3rd, Kearns AE, Atkinson EJ, et al. Secular trends in hip fracture incidence and recurrence. Osteoporos Int. 2009;20:687-694.

70. Dretakis KE, Dretakis EK, Papakitsou EF, Psarakis S, Steriopoulos K. Possible predisposing factors for the second hip fracture. Calcif Tissue Int. 1998;62:366-369.

71. Dolk T. Influence of treatment factors on the outcome after hip fractures. Upsala J Med Sci. 1989;94:209-221.

72. Schroder HM, Petersen KK, Erlandsen M. Occurrence and incidence of the second hip fracture. Clin Orthop Rel Res. 1993;289:166-169.

73. Yamanashi A, Tamazaki K, Kanamori M, et al. Assessment of risk factors for second hip fractures in Japanese elderly. Osteoporos Int. 2005;16:1239-1246.

74. Ip D, Ip FK. Elderly patients with two episodes of fragility hip fractures form a special subgroup. J Orthop Surg (Hong Kong). 2005;14: 245-248.

75. Lönnroos E, Kautiaien H, Karppi P, Hartikainen S, Kiviranta I, Sulkava R. Incidence of second hip fractures. A population based study. Osteoporos Int. 2007;18:1279-1285.

76. Berry SD, Samelson EJ, Hannan MT, et al. Second hip fracture in older men and women: the Framingham study. Arch Intern Med. 2007;167:1971-1976.

77. Thomas CD, Mayhew PM, Power J, et al. Femoral neck trabecular bone:loss with aging and role in preventing fracture. J Bone Miner Res. 2009;24:1808-1818.

78. Kulmala J, Sihvonen S, Kallinen M, Alen M, Kivirant I, Sipilä S. Balance confidence and functional balance in relation to falls in older persons with hip fracture history. J Geriatr Phys Ther. 2007;30:114-120.

79. Myers AH, Young Y, Langlois JA. Prevention of falls in the elderly. Bone. 1996A;18:87S-101S.

80. Greenspan SL, Myers ER, Kiel DP, et al. Fall direction, bone mineral density, and function: risk factors for hip fracture in frail nursing home elderly. Am J Med. 1998;104:539-545.

81. Sabick MB, Hay JG, Goel VK, Banks SA. Active responses decrease impact forces at the hip and shoulder in falls to the side. J Biomechanic. 1999;32:993-998.

82. Formiga F, Lopez-Soto A, Duaso E, et al. Characteristics of fall-related hip fractures in community-dwelling elderly patients according to cognitive status. Aging Clin Exp Res. 2008;20:434-438.

83. Luukinen H, Koski K, Laippala P, Kivela S. Factors predicting fractures during falling impacts among home-dwelling older adults. J Am Geriatr Soc. 1997;45:1302-1309.

84. Grisso JA, Kelsey JL, Strom BL, et al. Risk factors for falls as a cause of hip fracture in women. The North East Study Group. N Engl J Med. 1991;324:1326-1331.

85. Slemenda C. Prevention of hip fractures: risk factor modification. Am J Med. 1997;103:65S-73S.

86. Coupland C, Wood D, Cooper C. Physical inactivity is an independent risk factor for hip fracture in the elderly. J Epidemiol Health. 1993; 47:441-443

87. Wickham CA, Walsh K, Cooper C, et al. Dietary calcium, physical activity, and risk of hip fracture: a prospective study. BMJ. 1989;7: 889-892.

88. Cooper C, Barker DJP, Wickham C. Physical activity, muscle strength, and calcium intake in fracture of the proximal femur in Britain. BMJ 1988;297:1443-1446.

89. Cummings SR, Nevitt MC, Browner WS, et al. Risk factors for hip fractures in white women. Study of Osteoporotic Fractures Research Group. N Engl J Med. 1995;332:814-815.

90. Looker AC, Mussolino ME. Serum 25-hydroxyvitamin D and hip fracture risk in older US white adults. J Bone Miner Res. 2008;23: 143-150.

91. Sato Y, Inose M, Higuchi I, Higuchi F, Kondo I. Changes in the supporting muscles of the fractured hip in elderly women. Bone. 2002;30:325-330.

92. Bean N, Bennett KM, Lehmann AB. Habitus and hip fracture revisited: skeletal size, strength and cognition rather than thinness? Age Ageing $1995 ; 24: 481-484$. 
93. Farmer ME, Harris T, Madans JH, Wallace RB, Contoni-Huntley J, White LR. Anthropometric indicators and hip fracture. The NHANES I epidemiologic follow-up study. J Am Geriatr Soc. 1989;37:9-16.

94. Birge SJ. Osteoporosis and hip fracture. Clin Geriatr Med. 1993; 9:69-86.

95. Nielson CM, Bouxsein ML, Freitas SS, Ensrud KE, Orwoll ES; Osteoporotic Fractures in Men Research Group. Trochanteric soft tissue thickness and hip fracture in older men. J Clin Endocrinol Metab. 2009;94(2):491-496.

96. Lord SR, Ward JA, Williams P, Anstey KJ. Physiological factors associated with falls in older community-dwelling women. $\mathrm{J} \mathrm{Am}$ Geriatr Soc. 1994;42:1110-1117.

97. Dargent-Molina P, Schott AM, Hans D, et al. Separate and combined value of bone mass and gait speed measurements in screening for hip fracture risk: results from the EPIDOS study. Osteoporos Int. 1999;9:188-192.

98. Grisso JA, Kelsey JL, O Brien LA, et al. Risk factors for hip fracture in men. Hip fracture study group. Am J Epidemiol. 1997;145:786-793.

99. Hoidrup S, Sorenson TO, Stroger U, Lauritzen JB, Schroll M, Gronbaek M. Leisure-time physical activity levels and changes in relation to risk of hip fracture in men and women. Am J Epidemiol. 2001;154:60-68.

100. Suriyawongpaisal P, Rajatanavin R, Takkistien A, Wanvarie S, Apiyaawat P. Physical activity and risk factors for hip fracture in Thai men. Southeast Asian J Trop Med Public Health. 2001;32:196-203.

101. Cawthon PM, Fullman RL, Marshall L, et al. Osteoporotic fractures in men (MrOs) research group. J Bone Miner Res. 2008;23: 1037-1044.

102. Joakimsen RM, Magnus JH, Fonnebo V. Physical activity and predisposition for hip fractures: a review. Osteoporos Int. 1997;7:503-513.

103. Owusa W, Willet W, Ascherio A, Spiegelman D, Rimm E, Feskanich D, et al. Body anthropometry and the risk of hip and wrist fractures in men: results from a prospective study. Obesity Res. 1998;6:12-19.

104. Lau EM, Suriwongpaisal P, Lee JK, et al. Risk factors for hip fracture in Asian men and women: the Asian osteoporosis study. J Bone Min Res. 2001;16:572-580.

105. Farahmand BY, Michaelson K, Baron JA, Persson PG, Ljunghall S. Body size and fracture risk. Swedish Hip Fracture Study Group. Epidemiology. 2000;11:214-219.

106. Kanis J, Johnell O, Gullberg B, et al. Risk factors for hip fracture in men from southern Europe: the MEDOS study. Mediterranean Osteoporosis Study. Osteoporos Int. 1999;9:45-54.

107. Mussolino ME, Looker AC, Madans JH, Langlois JA, Orwoll ES. Risk factors for hip fracture in white men: The NHANES I Epidemiologic follow-up study. J Bone Min Res. 1998;13:918-924.

108. Langlois JA, Visser M, Davidoc LS, Maggi S, Li G, Harris TB. Hip fracture risk in older white men is associated with change in body weight from age 50 years to old age. Arch Int Med. 1998;158: 990-996.

109. De Laet C, Kanis JA, Oden A, et al. Body mass as a predictor of fracture risk: a meta-analysis. Osteoporos Int. 2005;16:1330-1338.

110. Langlois JA, Mussolino ME, Visser M, Looker AC, Harris T, Madans J. Weight loss from maximum body weight among middle-aged and older white women and the risk of hip fracture. The NHANES I epidemiologic follow-up study. Osteoporos Int. 2001;12:763-768.

111. Ensrud KE, Lipschutz RC, Cauley JA, et al. Body size and hip fracture risk in older women: a prospective study. Am J Med. 1997;103: 274-280.

112. Gardner TN, Simpson AHRW, Booth C, et al. Measurement of impact force, simulation of fall and hip fracture. Med Eng Phys. 1998;20: $57-65$.

113. Parker ED, Pereira MA, Virnig B, Folsom AR. The association of hip circumference with incident hip fracture in a cohort of postmenopausal women: the Iowa Women's Health Study. Ann Epidemiol. 2008;18:836-841.

114. Cumming RG, Klineberg RJ. Fall frequency and risk of hip fractures. J Am Geriatr Soc. 1994;42:774-778.
115. Maffulli N, Dougall TW, Brown MTF, Golden MHN. Nutritional differences in patients with proximal femoral fractures. Age Ageing. 1999;28:458-462.

116. Dretakis KE, Christadoulou NA. Significance of endogenic factors in the location of fractures of the proximal femur. Acta Orthop Scand. 1983;54:198-203.

117. Skalba P, Korfanty A, Mroczka W, Wojtowicz M. Changes of SHBG concentrations in postmenopausal women. Ginekol Pol. 2001;72: 1388-1392.

118. Abrahamsen B, Nielsen MF, Eskildsen P, Andersen JT, Walter S, Brizen K. Fracture risk in Danish men with prostate cancer: a nationwide register study. BJU Int. 2007;100:749-754.

119. Wei TS, Hu CH, Wang SH, Hwang KL. Fall characteristics, functional mobility and bone mineral density as risk factors of hip fracture in the community-dwelling ambulatory elderly. Osteoporos Int. 2001;12:1050-1055.

120. Johnell O, Kanis JA, Oden A, et al. Predictive value of BMD for hip and other fractures. J Bone Mineral Res. 2005;20:1185-1194.

121. Fox KM, Cummings SR, Williams E, Stone K. Femoral neck and intertrochanteric fractures have different risk factors: a prospective study. Osteoporos Int. 2000;11:1018-1023.

122. Fitzpatrick P, Kirke PN, Daly L, Van Rooij I, Dinn E, Burke H, et al. Predictors of first hip fracture and mortality in older women. Irish J Med Sci. 2001;170:49-53.

123. Cummings SR, Kelsey JL, Nevitt MC, O’Dowd KJ. Epidemiology of osteoporosis and osteoporotic fractures. Epidemiol Rev. 1985;7: 178-208.

124. Cummings SR, Nevitt MC. A hypothesis: the causes of hip fractures. J Gerontol. 1989;44:M108-M111.

125. Arden NK, Griffiths GO, Hart DJ, Doyle DV, Spector TD. The association between osteoarthritis and osteoporotic fracture: the Chingford study. Br J Rheumatol. 1996;35:1299-1304.

126. Boonen S, Dequeker J, Pelemans W. Risk factors for falls as a cause of hip fracture in the elderly. Acta Clin Belg. 1993;48:190-194.

127. Johnell O, Melton LJ III, Atkinson EJ, O Fallon WM, Kurland LT. Fracture risk in patients with parkinsonism: a population-based study in Olmsted County, Minnesota. Age Ageing. 1992;21:32-38.

128. Nevitt MC, Cummings SR, Kidd S, Black D. Risk factors for recurrent nonsyncopal falls. JAMA. 1989;261:2663-2668.

129. Buchner DM, Larson EB. Falls and fractures in patients with Alzheimer-type dementia. JAMA. 1987;257:1492-1495.

130. Christodoulou NA, Dretakis EK. Significance of muscular disturbances in the localization of fractures of the proximal femur. Clin Orthop Rel Res. 1984;187:215-217.

131. Schwartz AV, Sellmeyer DE, Ensrud KE, et al. Older women with diabetes have an increased risk of fracture: a prospective study. J Clin Endocrinol Metab. 2001;86:32-38.

132. Boonen S, Broos P, Haentjens P. Factors associated with hip fracture occurrence in old age. Implications in the postsurgical management. Acta Chir Belg. 1999;99:185-189.

133. Poor G, Atkinson EJ, O Fallen WM, Melton LJ III. Predictors of hip fractures in men. J Bone Min Res. 1995;10:1900-1907.

134. Grisso JA, Kelsey JL, Strom BL, et al. Risk factors for hip fracture in black women. The Northeast Hip Fracture Group. N Engl J Med. 1994;330:1555-1559.

135. French DD, Bass E, Bradham DD, Campbell RR, Rubenstein LZ. Rehospitalization after hip fracture: predictors and prognosis from a national veterans study. J Am Geriatr Soc. 2008;56:705-710.

136. Roche JJW, Wenn RT, Sahoto O, Moran CG. Effect of comorbidities and postoperative complications on mortality after hip fracture in elderly people: prospective observational cohort. BMJ. 2005;331:1374.

137. Guo Z, Wills P, Viitanen M, Fastbom J, Winblad B. Cognitive impairment, drug use, and the risk of hip fracture in persons over 75 years old: a community-based prospective study. Am J Epidemiol. 1998;148:887-892.

138. Hasegawa Y, Suzuki S, Wingstrand H. Risk of mortality following hip fracture in Japan. J Orthop Sci. 2007;12:113-117. 
139. Greenspan SL, Myers ER, Maitland LA, Resnick NM, Hayes WC. Fall severity and bone mineral density as risk factors for hip fracture in ambulatory elderly. JAMA. 1994;271:128-133.

140. Magaziner J, Simonsick EM, Kashner TM, Hebel JR, Kenzora JE. Predictors of functional recovery one year following hospital discharge for hip fracture: a prospective study. J Gerontol. 1990;45: M101-M107.

141. Clemenson L, Cumming RG, Roland M. Case-control study of hazards in the home and risk of falls and hip fractures. Age Ageing. 1996;25:97-101.

142. Huang Z, Himes JH, McGovern PG. Nutrition and subsequent fracture risk among a national cohort of white women. Am J Epidemiol. 1996;144:124-134.

143. Ivers RQ, Cumming RG, Mitchell P, Simpson JM, Peduto AJ. Visual risk factors for hip fracture in older people. $J$ Am Geriatr Soc. 2003;51:356-363.

144. Ivers RQ, Norton R, Cumming RG, Butler M, Campbell AJ.Visual impairment and risk of hip fracture. Am J Epidemiol. 2000;152: 633-639.

145. Pfister AK, McJunkin J, Santrock DA. Hip fracture outcomes and their prevention in Kanawha County, West Virginia. West Virginia Med J. 1999;95:170-174.

146. Lichtenstein MJ, Griffen MR, Cornell JE, Malcolm E, Ray WA. Risk factors for hip fractures occurring in the hospital. Am J Epidemiol. 2000;140:830-838.

147. Felson DT, Anderson JJ, Hannan MT, Milton RC, Wilson PW, Kiel DP. Impaired vision and hip fracture. The Framingham Study. J Am Geriatr Soc. 1989;37:495-500.

148. Rashiq S, Logan RFA. Role of drugs in fractures of the femoral neck. BMJ. 1986;292:861-863

149. Liu B, Anderson G, Mittmann N, et al. Use of selective serotoninreuptake inhibitors or tricyclic antidepressants and risk of hip fractures in elderly people. Lancet. 1998;351:1303-1307.

150. Rees LH, Besser GM, Jeffcoate WJ, Goldie DJ, Marks V. Alcohol induced pseudo-Cushing's syndrome. Lancet. 1977;1:726-728.

151. Hemenway D, Colditz GA, Willett WC, Stampfer MJ, Speizer FE. Fractures and lifestyle: effect of cigarette smoking, alcohol intake and relative weight on the risk of hip and forearm fractures in middle-aged women. Am J Public Health. 1988;78:1554-1558.

152. Pacher P, Ungvari Z. Selective serotonin-reuptake inhibitor antidepressants increase the risk of falls and hip fractures in elderly people by inhibiting cardiovascular ion channels. Med Hypotheses. 2001;57:469-471.

153. Sheppard MC, Holder R, Franklyn JA. Levothyroxine treatment and occurrence of fracture of the hip. Arch Int Med. 2002;162:338-343.

154. Jacqmin-Gadda H, Fourrier A, Commenges D, Dartigues JF. Risk for fractures in the elderly. Epidemiology. 1998;9:417-423.

155. Bolton JM, Metge C, Lix L, Prior H, Sareen J, Leslie WD. Fracture risk from psychotropic medications: a population-based analysis. J Clin Psychopharmacol. 2008;28:384-391.

156. Norton R, Campbell J, Lee JT, Robinson E, Butler M. Circumstances of falls resulting in hip fractures among older people. $J$ Am Geriatr Soc. 1997;45:1108-1112.

157. King MB, Tinetti ME. A multifactorial approach to reducing injurious falls. Clin Geriatr Med. 1996;12:745-759.

158. Allander E, Gullberg B, Johnell O, Kanis JA, Ranstam J, Elffors L. Circumstances around the fall in a multinational hip fracture risk study: a diverse pattern for prevention. Accid Anal Prev. 1998;30:607-616.

159. Lloyd BD, Williamson DA, Singh NA, et al. Recurrent and injurious falls in the year following hip fracture: a prospective study of incidence and risk factors from the Sarcopenia and Hip Fracture study. J Gerontol A Biol Sci Med Sci. 2009;64:599-609.

160. Fisher AA, Davis MW, Rubenach SE, et al. The site specific epidemiology of the hip fracture in the Australian Capital Territory with projections for the first half of the 21 st century: implications for clinical management and health services planning. Australasian $J$ Aging. 2007;26:45-51.
161. Ahmed LA, Schirme H, Bjornerem A, et al. The gender- and age-specific 10-year and lifetime absolute fracture risk in Tromse, Norway. Eur J Epidemiol. 2009;24:441-448.

162. Hiebert R, Aharonoff GB, Capla EL, Edol KA, Zuckerman JD, Koval JJ. Temporal and geographic variation in hip fracture rates for people aged 65 or older, New York State, 1985-1996. Am J Orthop. 2005;34:252-255.

163. Auron-Gomez M, Michota F. Medical management of hip fracture. Clin Geriatr Med. 2008;24:701-719.

164. Abrahamsen B, van Staa T, Ariely R, Olson M, Cooper C. Excess mortality following hip fracture: a systematic epidemiological review. Osteoporos Int. 2009;20:1633-1650.

165. Eklund F, Nordstrom A, Neovius M, et al. Variation in fracture rates by country may not be explained by differences in bone mass. Calcif Tissue Int. 2009;85:10-16.

166. Chang KP, Center JR, Nguyen TV, Eisman JA. Incidence of hip and other osteoporotic fractures in elderly men and women: Dubbo Osteoporosis Epidemiology Study. J Bone Miner Res. 2004;19: 532-536.

167. Boyce WJ, Vessey MP. Rising incidence of fracture of the proximal femur. Lancet. 1985;1:150-151.

168. Johal KS, Boulton C, Moran CG. Hip fractures after falls in hospital: a retrospective observational cohort study. Injury. 2009;40:201-204

169. Van Helden S, Van Geel AC, Geusens PP, et al. Bone and fall-related fracture risks in women and men with a recent clinical fracture. J Bone Joint Surg. 2008;90:241-248.

170. Grue EV, Kirkevold M, Ranhoff AH. Prevalence of vision, hearing, and combined vision and hearing impairments in patients with hip fracture. J Clin Nurs. 2009;18:3037-3049.

171. Piirtola M, Vahlberg T, Lopponen M, Raiha I, Isoaho R, Kivela SL. Fractures as predictors of excess mortality in the aged-a populationbased study with a 12-year follow-up. Eur J Epidemiol. 2008;23: 747-755.

172. Rapp K, Becker C, Lamb SE, Icks A, Klenk J. Hip fractures in institutionalized elderly people: incidence rates and excess mortality. J Bone Miner Res. 2008;23:1825-1831.

173. Moayyeri A, Soltani A, Larijani B, et al. Epidemiology of hip fracture in Iran: results from the Iranian Multicenter Study on Accidental Injuries. Osteoporos Int. 2006;17:1252-1257.

174. Davidson CW, Merrilees MJ, Wilkinson TJ, McKie JS, Gilchrist NL. Hip fracture mortality and morbidity - can we do better? $N Z$ Med J. 2001;114:329-332.

175. Myers AH, Robinson EG, Van Natta ML, Michelson JD, Collins K, Baker SP. Hip fractures among the elderly: factors associated with in-hospital mortality. Am J Epidemiol. 1991;134:1128-1137.

176. Stavrou ZP, Erginousakis DA, Loizides AA. Tzevelekos SA, Papagiannakos KP. Mortality and rehabilitation following hip fracture. Acta Orthop Scand. 1997;275(Suppl):89-91.

177. Cooper $\mathrm{C}$. The crippling consequences of fractures and their impact on quality of life. Am J Med. 1997;103 Part A:12S-19S.

178. de Luise C, Brimacombe M, Pederson L, Sorenson HT. Comorbidity and mortality following hip fracture: a population-based cohort study. Aging Clin Exp Res. 2008;20:412-418.

179. Karlsson M, Nilsson J, Sernbo I, Redlund-Johnell I, Johnell O, Obrant KJ. Changes of bone mineral mass and soft tissue composition after hip fracture. Bone. 1996;18:19-22.

180. Parker MJ, Palmer CR. Prediction of rehabilitation after hip fracture Age Ageing. 1995;24:96-98.

181. Myers AH, Palmer MH, Engel BT, Warrenfeltz DJ, Parker JA. Mobility in older patients with hip fractures: examining prefracture status, complications, and outcomes at discharge from the acute-care hospital. J Orthop Trauma. 1996b;10:99-107.

182. Formigo F, Navarro M, Duaso E, et al. Factors associated with hip fracture-related falls among patients with a history of recurrent falling. Bone. 2008;43:941-944.

183. Barangan JD. Factors that influence recovery from hip fracture during hospitalization. Orthop Nurs. 1990;9:19-29. 
184. Ceder L, Svensson K, Thorngren K. Statistical prediction of rehabilitation in elderly patients with hip fractures. Clin Orthop Rel Res. 1980;152:185-190.

185. Fox KM, Hawkes WG, Hebel JR, et al. Mobility after hip fracture predicts health outcomes. J Am Geriatr Soc. 1988;46:169-173.

186. Runge M, Schact E. Proximal femoral fractures in the elderly: pathogenesis, sequelae, interventions. Rehabil (Stuttg). 1999;38: $160-169$.

187. Angthong C, Suntharapa T, Harnroongroj T. Major risk factors for the second contralateral hip fracture in the elderly. Acta Orthop Traumatol Turc. 2009;43:193-198.

188. Stolee P, Poss J, Cook RJ, Byrne K, Hirdes JP. Risk factors for hip fracture in older home care clients. J Gerontol A Biol Sci Med Sci. 2009;64:403-410.

189. Kanis JA, Johansson H, Oden A, et al. Assessment of fracture risk. Eur J Radiol. 2009; [Epub ahead of print].

190. Chen JS, Sambrook PN, Simpson JM, et al. Risk factors for hip fracture among institutionalised older people. Age Ageing. 2009;38: 429-434.

191. Karlsson MK, Nordqvist A, Karlsson C. Physical activity, muscle function, falls and fractures. Food Nutr Res. 2008;52. DOI: 10.3402/ fnr.v52i0.1920.

192. Trimpou P, Landin-Wilhelmsen K, Odén A, Rosengren A, Wilhelmsen L. Male risk factors for hip fracture-a 30-year follow-up study in 7,495 men. Osteoporos Int. 2009 May 28; [Epub ahead of print].

193. Ryg J, Rejnmark L, Overgaard S, Brixen K, Vestergaard P. Hip fracture patients at risk of second hip fracture-a nationwide population-based cohort study of 169,145 cases during 1977-2001. J Bone Miner Res. 2009;24:1299-1307.

194. Shao CJ, Hsieh YH, Tsai CH, Lai KA. A nationwide seven-year trend of hip fractures in the elderly poplation of Taiwan. Bone. 2009;44: 125-129.

195. Dorner T, Weichselbaum E, Lawrence K, Viktoria Stein K, Rieder A. Austrian osteoporosis report: epidemiology, lifestyle factors, public health strategies. Wien Med Wochenschr. 2009;159:221-229.

196. Tanriover MD, Oz SG, Tanriover A, et al. Hip fractures in a developing country: osteoporosis frequency, predisposing factors and treatment costs. Arch Gerontol Geriatr. 2009 May 27; [Epub ahead of print].

197. Bass E, French DD, Bradham DD. A national perspective of Medicare expenditures for elderly veterans with hip fractures. $J$ Am Med Dir Assoc. 2008;9:114-119.

198. Lawrence TM, White CT, Wenn R, Moran CG. The current hospital costs of treating hip fractures. Injury. 2005;36:88-91.

199. Tromp AM, Ooms ME, Poo-Snijders C, Roos JC, Lips P. Predictors of fractures in elderly women. Osteoporos Int. 2000;11:134-140.

200. Margolis KL, Ensrud KE, Schreiner PJ, Tabor HK. Body size and risk for clinical fractures in older women. Study of Osteoporotic Fractures Research Group. Ann Intern Med. 2000;133:123-127.

201. Cummings SR, Nevitt MC. Non-skeletal determinants of fractures: The potential importance of the mechanism of falls. Study of Osteoporotic Fractures Research Group. Osteoporos Int. 1994;4 Suppl 1: $67-70$.

202. Wolinsky FD, Fitzgerald JF. The risk of hip fracture among noninstitutionalized older adults. J Gerontol A Biol Sci Med Sci. 1994;49: S165-S175.

203. Jones G, Nguyen T, Sambrook PN, Lord SR, Kelly PJ, Eisman JA. Osteoarthritis, bone density, postural stability, and osteoporotic fractures: a population based study. J Rheumatol. 1995;22: 921-925.

204. Parker MJ, Twemlow TR, Pryor G. A.Environmental hazards and hip fractures. Age Ageing. 1996;25:322-325.

205. Chen Z, Maricic M, Aragaki AK, et al. Fracture risk increases after the diagnosis of breast or other cancers in postmenopausal women: results from the Women's Health Initiative. Osteoporosis Int. 2009;20: $527-536$.
206. Tafuri S, Martinelli D, Balducci MT, Fortunato F, Prato R, Germinario C. Epidemiology of femoral neck fractures in Puglia (Italy): an analysis of existing data. Ig Sanita Pubbl. 2008;64:623-636.

207. Collins TC, Ewing SK, Diem SJ, et al; for the Osteoporotic Fractures in Men (MrOS) Study Group. Peripheral arterial disease is associated with higher rates of hip bone loss and increased fracture risk in older men. Circulation. 2009;119:2305-2312.

208. Wolinsky FD, Bentler SE, Liu L, Obrizan M, Cook EA, Wright KB, et al. Recent hospitalization and the risk of hip fracture among older Americans. J Gerontol A Biol Sci Med Sci. 2009;64:249-255.

209. Sahni S, Hannan MT, Gagnon D, et al. Protective effect of total and supplemental vitamin C intake on risk of hip fracture-a 17-year follow-up from the Framingham Osteoporosis Study. Osteoporos Int. 2009;20:1853-1861.

210. Kristensen MT, Bandholm T, Bencke J, Ekdahl C, Kehlet H. Kneeextension strength, postural control and function are related to fracture type and thigh edema in patients with hip fracture. Clin Biomech. 2009;24:218-224.

211. Hagino H, Katagari H, Okano T, Yamamoto K, Teshima R. Increasing incidence of hip fracture in Tottori Prefecture, Japan: trend from 1986-2001. Osteoporos Int. 2005;16:1963-1968.

212. Hernandez JL, Olmos JM, Alonso MA, et al. Trends in hip fracture epidemiology over a 14-year period in a Spanish population. Osteoporos Int. 2006;17:464-470.

213. Giversen IM. Time trends of age-adjusted incidence rates of first hip fractures: a register-based study among older people in Viborg County, Denmark, 1987-1997. Osteoporos Int. 2006;17:552-564.

214. Lönnroos E, Kautiainen H, Karppi P, Huusko T, Hartikainen S, Kiviranta I, et al. Increased incidence of hip fractures. A population based-study in Finland. Bone. 2006;39:623-627.

215. Icks A, Haastert B, Wildner M, Becker C, Meyer G. Trend of hip fracture incidence in Germany 1995-2004: a population-based study. Osteoporos Int. 2008;19:1139-1145.

216. Holt G, Smith R, Duncan K, Hutchison JD, Reid D. Changes in population demographics and the future incidence of hip fracture. Injury. 2009;40:722-726.

217. Dodds MK, Codd MB, Looney A, Mulhall KJ. Incidence of hip fracture in the Republic of Ireland and future projections: a population-based study. Osteoporos Int. 2009 Apr 1; [Epub ahead of print].

218. Jette AM, Harris B, Cleary PD, Campion EW. Functional recovery after hip fracture. Arch Phys Med Rehabil. 1987;68:735-740.

219. Bonar SK, Tinetti ME, Speechley M, Cooney LM. Factors associated with short- versus long term skilled nursing facility placement among community-living hip fracture patients. J Am Geriatr Soc. 1990;38:1139-1144.

220. Jalovaara $P$, Virkkunen $H$. Quality of life after primary hemiarthroplasty for femoral neck fracture. Six year follow-up of 185 patients. Acta Orthop Scand. 1991;62:208-217.

221. Marottoli RA, Berkman LF, Cooney LM Jr. Decline in physical function following hip fracture. $J$ Am Geriatr Soc. 1992;40:861-866.

222. Aharonoff GB, Koval KJ, Skovron ML, Zuckerman JD. Hip fractures in the elderly: predictors of one year mortality. J Orthop Trauma. 1997;11:162-165.

223. Wolinsky FD, Fitzgerald JF, Stump TE. The effect of hip fracture on mortality, hospitalization, and functional status: a prospective study. Am J Public Health. 1997;87:398-403.

224. Koike Y, Imaizumi H, Takahashi E, Matsubara Y, Komatsu H. Determining factors of mortality in the elderly with hip fractures. Tohoku J Exp Med. 1999;188:139-142.

225. Giaquinto S, Majola II, Palma E, Roncacci S, Sciarra A, Vittoria E. Very old people can have a favorable outcome after hip fracture: 58 patients referred to rehabilitation. Arch Gerontol Geriatr. 2000;1: 13-18.

226. Maggio D, Ubaldi E, Simonelli G, Cenci S, Pedone C, Cherubini A. Hip fracture in nursing homes: an Italian study on prevalence, latency, risk factors, and impact on mobility. Calc Tissue Int. 2001;68: $337-341$ 
227. Van Balen R, Steyerberg EW, Polder JJ, Ribbers TL, Habbema JD, Cools HJ. Hip fracture in elderly patients: outcomes for function, quality of life, and type of residence. Clin Orthop Rel Res. 2001;390: 232-243.

228. Kirke PN, Sutton M, Burke H, Daly L.Outcome of hip fracture in older Irish women: a 2 year follow-up of subjects in a case-control study. Injury. 2002;1654:1-5.
229. Leboff MS, Narwecker R, LaCroix A, et al. Homocysteine levels and risk of hip fracture in postmenopausal women. J Clin Endocrinol Metab. 2009;94:1207-1213.

230. Clinton J, Franta A, Polissar NL, et al. Proximal humeral fracture as a risk factor for subsequent hip fractures. J Bone Joint Surg Am. 2009;91:503-511.

\section{Publish your work in this journal}

The International Journal of General Medicine is an international, peer-reviewed open-access journal that focuses on general and internal medicine, pathogenesis, epidemiology, diagnosis, monitoring and treatment protocols. The journal is characterized by the rapid reporting of reviews, original research and clinical studies across all disease areas.
A key focus is the elucidation of disease processes and management protocols resulting in improved outcomes for the patient.The manuscript management system is completely online and includes a very quick and fair peer-review system. Visit http://www.dovepress.com/ testimonials.php to read real quotes from published authors.

Submit your manuscript here: http://www.dovepress.com/international-journal-of-general-medicine-journal 